\title{
High renewable energy penetration scenarios and their implications for urban energy and transport systems
}

\author{
Dr. Sven Teske \\ Corresponding author: sven.teske@uts.edu.au, \\ University of Technology Sydney (UTS), \\ 235 Jones Street, Ultimo, 2007 Sydney, Australia
}

Dr. Thomas Pregger, Dr. Sonja Simon, Dr. Tobias Naegler

German Aerospace Center (DLR), Department of Systems Analysis and Technology Assessment, Institute of Engineering Thermodynamics, Pfaffenwaldring 38-40, 70569 Stuttgart, Germany

\begin{abstract}
To meet the terms of the 2015 Paris Agreement, the global energy system must be entirely decarbonized by the end of this century. Two scenarios have been developed: a reference case (REF) and an advanced $100 \%$ renewable energy scenario (ADV). ADV reflects the trends in global energy systems and will decarbonize the entire energy system by 2050 . Those results are compared with the IPCC AR5 450 ppm scenarios, in terms of the 2050 energy demand projections - primary and final energy — and the demands for the transport and building sectors because they are important in urban environments. The results are further discussed with regard to the impact on urban infrastructures and the role of megacities in the global energy consumption pattern. Under the assumption that urbanization rates will remain at the 2015 level until 2050, the annual energy demand for buildings in urban areas is expected to increase by $27 \mathrm{EJ}$ under the reference scenario (REF), from $57 \mathrm{EJ}$ to $84 \mathrm{EJ}$ per year, whereas ADV would lead to an overall reduction to 46 EJ per year by 2050, while the population and GDP continue to grow. Overall, the global energy demand in the transport sector is expected to increase by over $60 \%$ by 2050 under REF, whereas the deep mitigation pathway (ADV) reduces the transport energy demand below that of the base year, to $70 \mathrm{EJ}$ per year. This is a significant reduction, even compared with other $450 \mathrm{ppm}$ scenarios, and can be achieved by a drastic shift to electric mobility in response to vehicle efficiency
\end{abstract}

standards, a phasing-out of combustion engines in the transport sector by 2030, and a modal shift in favor of urban public transport. The global energy demand for the building sector in ADV shows a smaller deviation in comparison to other $450 \mathrm{ppm}$ scenarios than that for the transport sector.

Key words: low-carbon scenario; global demand projection; energy efficiency; efficiency standard; global energy scenario; $\mathrm{CO}_{2}$ reduction; renewable energy; urban infrastructure; comparative AR5 450 ppm scenario

\section{Highlights}

- $\quad$ Comparison of deep-decarbonization scenarios reveals large differences in final energy demand projections

- $\quad$ The projected electricity demand for 2050 varies significantly, between $65,000 \mathrm{TWh} / \mathrm{yr}$ and 25,000 TWh/yr

- The presented low-carbon ADV scenario combines $100 \%$ renewable energy for all sectors with high efficiency

- $100 \%$ renewable energy scenarios use high electrification rates for transport and the heating sector

- $\quad$ Estimated $\mathrm{CO}_{2}$ reduction potential for urban buildings accounts for $35 \mathrm{Gt} \mathrm{CO}_{2}$ by 2050 


\section{Background to the mitigation scenarios presented}

Article 2 (a) of the 2015 Paris Agreement [1] states that "Holding the increase in the global average temperature to well below $2^{\circ} \mathrm{C}$ above pre-industrial levels and pursuing efforts to limit the temperature increase to $1.5^{\circ} \mathrm{C}$ above pre-industrial levels, recognizing that this would significantly reduce the risks and impacts of climate change (...)".The objective of this paper is to compare various deepmitigation scenarios that use the whole range of energy technologies_-including carbon capture and storage (CCS) and nuclear-with a scenario that only uses renewable and energy-efficient technologies. The focus is on projected energy demand for urban buildings and transport, the resulting emissions and the possible impacts on the urban infrastructure. The German Aerospace Center developed the Energy [R]evolution 2015, a global $100 \%$ renewable energy scenario [2]**, in close cooperation with Greenpeace and renewable industry associations. The climate mitigation pathway presented here further increases the proportion of renewable energy relative to the Energy [R] evolution scenarios published earlier [3], [4] (which served as the baseline mitigation scenario in Edenhofer et al. [5]) from $80 \%$ to $100 \%$ by 2050 , phasing out energy-related $\mathrm{CO}_{2}$ entirely by 2050 . The assumptions and results of this pathway are compared with the results of other climate mitigation pathways from the AR5 database [21].

\section{Key questions addressed in this paper:}

1. What developments are required to meet the energy demand and renewable energy supply for a $100 \%$ renewable energy pathway?

2. What are the possible changes in the urban building energy demand?

3. What are the potential impacts of $100 \%$ renewable energy pathways on urban infrastructures?

In this paper, we present the methodology, assumptions, and key results of two global scenarios and compare them with those of AR5 scenarios. A subsequent section focuses on urban environments.

\section{Methods and assumptions \\ The scenarios}

The scenarios have been developed using the Mesap/PlaNet simulation model. Mesap/Planet contains a detail-rich description of the entire energy system - from useful energy to primary energy demand in the industry, transport, buildings and transformation sectors. Main model parameters are calibrated with the IEA energy balances in the past. The forward projection of those model parameters takes into account various technical, economic and social constraints and interdependencies between sectors and technologies as well as results and insights from other (modelling) studies. In this way, Mesap/PlaNet allows taking into account broad expert knowledge when developing target-oriented energy scenarios. A more detailed description can be found in Schlenzig [6]. The Reference case (REF) is used as the baseline scenario for comparison with other scenarios and is based on the Current Policies scenarios published by the International Energy Agency (IEA) in World Energy Outlook 2014 [43]. It considers only existing international and national energy and environmental policies. Its assumptions include continuing progress in electricity and gas market reforms, the liberalization of cross-border energy trade, and recent policies designed to combat environmental pollution, without additional climate policies. The IEA's projections to 2040 are extended by extrapolating their key macroeconomic and energy indicators forward to 2050, on the assumption that these parameters will continue to follow the presumed trends between 2035 and 2040 over the following decade. The Advanced Energy [R]evolution (ADV) scenario includes significant efforts to fully exploit the large potential for energy efficiency using mandatory efficiency standards. At the same time, various renewable energy sources are integrated to a large extent for heat and electricity generation and the production of biofuels and hydrogen for the transport sector. The latter will require a strong role for hydrogen and other synthetic fuels in heavy-duty vehicles, shipping, and aviation, complementary to electric battery vehicle concepts for passenger cars, and (limited) biofuels. Furthermore, in the heating- and cooling sector, electricity will play important roles. In ADV, hydrogen plays a minor role in the building sector (2\% by 2050) and is used to substitute for natural gas. In the power sector, natural gas will also be replaced by hydrogen. CCS technologies have not been taken into account in the ADV.

Methodology, approach, and main premises $\mathrm{ADV}$ is a target-oriented scenario developed with a primarily "bottom-up" approach (technologydriven). Presumed increases in population, GDP, specific energy demands, and the deployment of renewable energy technologies are important drivers. The supply scenarios were calculated using an accounting framework [6], and the methodology has been also documented in Giles et al. [7]. The model has been applied to develop five global energy scenarios between 2004 and 2015 and over 50 national and regional scenarios.

REF and related specific data - such as efficiencies, load factors, and demand intensities - are based on the Current Policies scenario published by the IEA in World Energy Outlook 2014 and uses the same regional breakdown in 10 world regions (see Appendix Table 14). 
The energy demand projections and efficiency potentials for ADV are based on Graus et. al. [8], [9], involving a global annual reduction in energy intensity of 3.55\% in ADV, compared with 1.85\% in REF. The annually utilized bio energy will be limited to 80 EJ by 2050, to meet Greenpeace sustainability criteria. This amount is based on a global bio energy assessment survey [10]. The expansion of renewable energies defined in ADV are based on recent technology trends [11]*, regional renewable energy potentials, current and future deployment costs [12], [13], and market development projections of the renewable energy industry [14], [15], [16], [24], [17], [18]. In ADV, the annual markets for the dominant renewable power generation technologies will maintain the annual growth rates of the past decade (2004-2015) until 2030 to sustain the expansion rates of the renewable energy RE industry, and will decline to one-digit values between 2030 and 2050 (Table 17, appendix). The annual market for solar photovoltaic systems will increase from $51 \mathrm{GW}$ in 2015 to 280 GW by 2050; that for concentrated solar power plants will increase from around $1 \mathrm{GW}$ to $96 \mathrm{GW}$, and that for wind power from $64 \mathrm{GW}$ to $250 \mathrm{GW}$ by 2050. The model uses annual growth rates for all supply technologies. The future development pathways for cars and other transportation technologies are based on Schmidt et al. [19] and demand development is calculated from energy intensities based on Oezdemir et al. [44].

Population development: The IEA World Energy Outlook 2014 [43] and the ADV scenario were calculated with an average global population growth of $0.8 \%$ per year over the period 2015-2050, increasing from 7 billion to 9.9 billion people by 2050 (Table 13), based on the UN DESA World Population Prospect 2012 (medium fertility variant) [20]. Later UNDESA editions have not been taken into account.

Economic growth is a key driver of energy demand. The average increase in the global gross domestic product (GDP) between 2012 and 2025 is assumed to be $3.4 \%$. The projections based on the regional breakdown until 2050 [43] are shown in Table 14.

\section{Methodology: Calculation of urban building energy demand}

IEA [26] uses a breakdown in transport, industry, and other sectors. Other sectors are further subdivided into residential, commercial, and public services buildings, agriculture and forestry, fishing, and 'non-specified'. REF and ADV use the statistical breakdown of the percentages for each region and sector for their projections to 2050, and do not include further sector-specific projections. In this paper, we focus on the transport and building sectors.

Based on IEA [26], the final energy demand for residential, commercial, and public services buildings was calculated from regional populations and urbanization (see Table 1). The results are presented under the term "buildings". This pragmatic methodology leads to inaccuracies, mainly because the different subdivisions have different savings potentials in all 10 regions. However, a more detailed analysis would have exceeded the scope of this study, but further research is required. The World Bank database [41] provides urbanization rates for 2015 (see Table 1), which have been used to estimate the urban building demand. No projections for the future development of urbanization rates by region have been made because they are highly uncertain.

\begin{tabular}{|l|l|}
\hline Urbanization rates in 2015 in \% (World Bank database) \\
\hline Region & $\mathbf{2 0 1 5}$ \\
\hline OECD North America & $82 \%$ \\
\hline OECD Asia Oceania & $57 \%$ \\
\hline OECD Europe & $75 \%$ \\
\hline Eastern Europe/Eurasia & $71 \%$ \\
\hline India & $18 \%$ \\
\hline China & $57 \%$ \\
\hline Other Asia & $17 \%$ \\
\hline Latin America & $49 \%$ \\
\hline Middle East & $35 \%$ \\
\hline Global average & $\mathbf{5 4 \%}$ \\
\hline Table 1: Urbanization rates by region (WB 2015)
\end{tabular}

Table 1: Urbanization rates by region (WB 2015)

The use of a constant urbanization rate may lead to an underestimate of the future urban energy demand for building, because a United Nations analysis [42] has suggested that urbanization rates are likely to increase. Therefore, the results are conservative estimates and further research is required.

\section{Global results: comparing different mitigation pathways}

The detailed results of the $100 \%$ renewable energy pathway ADV are compared - as far as possible with the 450 ppm scenarios published in the IPCC database [21]**, derived with the following models: Ecofys, IMAGE 2.4, Message V4,

MiniCam_EMF22, and REMIND 1.5. The transport projections are also compared with IMACLIM V1.1 and POLES EMF27 because these parameters are not available in the previously mentioned models.

Energy demand development:

Under the REF scenario which is based on the IEA Current Policies scenario, the total final energy demand will increase by $65 \%$, from the current $326.9 \mathrm{EJ} / \mathrm{yr}$ to $539 \mathrm{EJ} / \mathrm{yr}$ in 2050 . ADV will lead to a peak demand in 2020, with a total consumption of $355 \mathrm{EJ} / \mathrm{yr}$ (7\% below that of REF), which will remain at that level for about a decade. With the fast electrification of the transport sector, and the greater 
role of public transport, the overall final energy demand will drop below current levels before 2040 and reach $279 \mathrm{EJ} / \mathrm{yr}$ by 2050 (15\% below the current global demand). Table 2 shows that the ADV and TER 2011 energy demand projections are significantly below those of other AR5 450 ppm scenarios.

\begin{tabular}{|r|l|c|}
\hline Model & Scenario & $\begin{array}{c}\mathbf{2 0 5 0} \\
{[\mathbf{E J} / \mathbf{y r}]}\end{array}$ \\
\hline Mesap/PlaNet & ADV & 279 \\
\hline Ecofys & TER 2011 & 261 \\
\hline IMAGE 2.4 & EMF27-450-FullTech & 426 \\
\hline Message V4 & AMPERE3-450- & 543 \\
\hline REMIND 1.5 & LIMITS 450 & 500 \\
\hline Max. & AMPERE3-450P & 560 \\
\hline Average & LIMITS-RefPol-450 & 467 \\
\hline Min. & TER 2011 & 261 \\
\hline
\end{tabular}

Table 2: Final energy demand projections for 2050

Electricity replaces fuels: In the ADV, the total electricity demand will increase from about 18,860 TWh/yr in 2012 to 40,163 TWh/yr by 2050.

Efficiency measures in the industry, residential, and service sectors will avoid the generation of about 16,700 TWh/yr compared with REF (42,622 $\mathrm{TWh} / \mathrm{yr}$ ), but substantially increase the electricity demand in the transport sector. Therefore, the electricity demands in 2050 for REF and ADV are within the same order of magnitude. Around 8,100 TWh/yr will be used in 2050 for electric vehicles and rail transport, around 5,100 TWh/yr for hydrogen, and 3,600 TWh/yr for synthetic liquid fuel generation for the transport sector (excluding bunkers). The electricity share of the total final energy demand will increase from 23\% in 2015 to $52 \%$ in 2050 in ADV, but to $28 \%$ in REF. The ADV projection is consistent with most AR $450 \mathrm{ppm}$ scenarios (Table 3).

\begin{tabular}{|c|c|c|}
\hline Model & Scenario & $\begin{array}{c}2050 \\
{[\mathrm{TWh} / \mathrm{yr}]}\end{array}$ \\
\hline Mesap/PlaNet & $\mathrm{ADV}$ & 40,163 \\
\hline Ecofys & TER 2011 & 35,417 \\
\hline IMAGE 2.4 & EMF27-450-FullTech & 36,171 \\
\hline Message V4 & AMPERE3-450P & 42,760 \\
\hline REMIND 1.5 & LIMITS 450 & 58,882 \\
\hline Max. & EMF27-450-NoCCS & 65,178 \\
\hline Average & EMF27-450-FullTech & 44,537 \\
\hline Min. & $\begin{array}{c}\text { AMPERE2-450-Conv- } \\
\text { HST }\end{array}$ & 26,208 \\
\hline
\end{tabular}

Reducing global heat demand in buildings: Under ADV, consumption equivalent to about $76 \mathrm{EJ} / \mathrm{yr}$ will be avoided through efficiency gains by 2050 compared with REF. This is attributable to energyrelated renovation of the existing stock of residential buildings, the introduction of low energy standards for buildings and electrical appliances, the 'passive climatisation' of new buildings, and highly efficient air-conditioning systems.
Heating supply: The proportion of renewable energy in ADV will increase from $21 \%$ to $43 \%$ of the global heat demand in 2030 and to $94 \%$ in 2050 . Up to 2030 , biomass will remain the main contributor to the growing market share. After 2030, the continuing growth of solar collectors and the growing proportions of geothermal and environmental heat and heat from renewable hydrogen will further reduce fossil fuel consumption. ADV will result in the complete substitution of the remaining gas consumption (2\% in 2050) by hydrogen generated from renewable electricity.

Electricity generation: By 2050, the proportion of global renewable power generation will reach $100 \%$ in ADV. Wind, photovoltaic (PV) systems, concentrated solar power (CSP), and geothermal energy will contribute $72 \%$ of the total electricity generation, whereas hydro power will supply $7 \%$. By 2025, the proportion of renewable power generated will reach $47 \%$, and $64 \%$ by 2030 . The installed capacity of renewable energy will reach about 9,500 GW in 2030 and 23,600 GW by 2050. $\mathrm{ADV}$ will result in a high proportion of variablepower-generating sources (PV, wind, and ocean), reaching $36 \%$ by 2030 and 55\% by 2050 .

Transport: The REF transport energy demand will increase by around 65\% from $90 \mathrm{EJ} / \mathrm{yr}$ in 2012 to $148 \mathrm{EJ} / \mathrm{yr}$ in 2050. In comparison, ADV will save $62 \%$ (92 EJ/yr) in 2050. By 2030, electricity will provide $19 \%$ of the transport sector's total energy demand, whereas in 2050, the share will be $52 \%$ in ADV. Hydrogen and other synthetic fuels generated with renewable electricity are complementary options that will further increase the proportion of renewable energy used in the transport sector. In 2050, ADV assumes $14 \mathrm{EJ} / \mathrm{yr}$ of hydrogen in the transport sector. The transport demand for ADV is by far the lowest of all the AR5 450 ppm scenarios (Table 4). A breakdown of road, rail, aviation, and marine transport demands is not available from the AR5 scenario database, so no further comparison is possible. ADV will reduce the final energy demand for road transport by $49 \%$ and increase that for rail by $300 \%$, whereas those for navigation and aviation will remain constant until 2050.

\begin{tabular}{|l|l|c|}
\hline Model & Scenario & $\begin{array}{c}\mathbf{2 0 5 0} \\
{[\mathbf{E J} / \mathbf{y r}]}\end{array}$ \\
\hline Mesap/PlaNet & ADV & 57 \\
\hline Ecofys & TER 2011 & 73 \\
\hline IMAGE 2.4 & EMF27-450-FullTech & 109 \\
\hline Message V4 & AMPERE3-450 & 170 \\
\hline REMIND 1.5 & LIMITS 450 & 156 \\
\hline Max. & AMPERE3-450P & 191 \\
\hline Average & $\begin{array}{c}\text { AMPERE2-450- } \\
\text { NoCCS-OPT }\end{array}$ & 137 \\
\hline Min. & ADV & 57 \\
\hline
\end{tabular}

Table 4: Transport demand projections for 2050 
Energy-related $\mathrm{CO}_{2}$ emissions: Under REF, energyrelated $\mathrm{CO}_{2}$ emissions will increase by $56 \%$ between 2012 and 2050. ADV will decarbonize the entire energy system by 2050. By 2030, global $\mathrm{CO}_{2}$ emissions will be at 1990 levels, and by 2040, a further $60 \%$ reduction will be achieved. The total carbon emissions between 2012 and 2050 will total $667 \mathrm{Gt} \mathrm{CO}_{2}$ in ADV. In comparison, REF will generate 1,400 Gt of $\mathrm{CO}_{2}$ between 2012 and 2050 . ADV will not entail any further greenhouse gases (GHG) emissions and will end in 2050.

Primary energy: The primary energy demand under REF will increase from $534 \mathrm{EJ} / \mathrm{yr}$ to $860 \mathrm{EJ} / \mathrm{yr}$ in 2050, whereas that under ADV will be $450 \mathrm{EJ} / \mathrm{yr}$ in 2050. This value is among the lowest for any scenario analyzed (Table 5). The only remaining fossil fuels are assumed to meet non-energy needs, such as petrochemical and steel products.

\begin{tabular}{|r|l|c|}
\hline Model & Scenario & $\begin{array}{c}\mathbf{2 0 5 0} \\
{[\mathbf{E J} / \mathbf{y r}]}\end{array}$ \\
\hline Mesap/PlaNet & ADV & 453 \\
\hline Ecofys & TER 2011 & 385 \\
\hline IMAGE 2.4 & EMF27-450-FullTech & 584 \\
\hline Message V4 & AMPERE3-450 & 719 \\
\hline REMIND 1.5 & LIMITS 450 & 670 \\
\hline Max. & $\begin{array}{l}\text { AMPERE2-450- } \\
\text { LimSW-OPT }\end{array}$ & 767 \\
\hline Average & LIMITS-RefPol-450 & 629 \\
\hline Min. & TER 2011 & 385 \\
\hline
\end{tabular}

Table 5: Primary energy demand projections for 2050

Feasibility of $100 \%$ renewable energy scenarios Whether $100 \%$ renewable energy scenarios are feasible is currently under discussion in the scientific literature Heard et al. [22]*, Esteban et al.[23] and Brown et al. [25]*. In particular, the feasibility of integrating large quantities of variably generated power (solar and wind), transmission requirements, and ancillary service requirements are debated. Brown et al. [25] address these concerns and provide concrete examples in which renewable power generation already provides almost $100 \%$ of regional electricity demands, such as in Paraguay (99\%), Norway (97\%), and Costa Rica (93\%) In 2016, the highest variable renewable electricity shares were in Denmark (37.6\%), Ireland (24\%) and Portugal (19.7\%) [24], [25] where synchronous generators from state-of-the-art wind turbines, as well as solar photovoltaic systems and storage units, were "coupled to the grid with inverters, which have no inherent inertia and low fault current, but can control voltage with both active and reactive power." However, further research is required and systems analyses should be undertaken in the future for all climate-mitigation pathways, not only those with high proportions of renewable energy.

\section{Urban climate mitigation pathways}

Cities are home to over half the world's population (3.96 billion people), which is expected to increase to 5.1 billion by 2030 [42]. The technical requirements for $100 \%$ renewable energy trajectories for urban environments will shape future infrastructural requirements. In the following section, we provide a brief overview of the energy demand projections for the presented trajectories and their expected impacts on infrastructural needs in urban areas. We again compare global sectorial results with those for selected $450 \mathrm{ppm}$ scenarios (see section 3).

Energy demand pathways for the building sector In most world regions in the base year 2012, the residential energy demand was larger than the commercial and public services demands (except in OECD Asia Oceania).

Fuel and heat use represent the largest share of the total final energy demand in this sector. The share ranges from 51\% for OECD North America to 95\% for Africa. The residential sector has the largest enduse of fuels and heat, ranging between $44 \%$ in OECD Asia Oceania to $91 \%$ in Africa.

Although residential buildings use a larger share of fuel and heat than commercial buildings, the consumption of electricity is more evenly spread over the subsectors: $48 \%$ of electricity is used in residential buildings, $40 \%$ in commerce and public services, and the remainder in other economic activities. The use of electricity in the services sector depends strongly on the region, and ranges from $16 \%$ in India to 55\% in OECD Asia Oceania. The building sector (as defined in section 2) consumes about $40 \%$ (including electricity) and $26 \%$ (excluding electricity) of the global final energy, a share expected to increase under REF from $130 \mathrm{EJ} / \mathrm{yr}$ in 2012 to more than $187 \mathrm{EJ} / \mathrm{yr}$ in 2040 (IEA WEO 2014). By 2050, the building sector will consume $203 \mathrm{EJ} / \mathrm{yr}$ in REF, 64\% more than in the base year. Within this sector, the electricity demand has a relative growth of $130 \%$, whereas the fuel demand is expected to increase most slowly, from $92 \mathrm{EJ} / \mathrm{yr}$ in 2012 to $116 \mathrm{EJ} / \mathrm{yr}$ in 2050. The energy demand in buildings under REF will grow considerably, with the highest demand in OECD Americas (33 EJ/yr), followed by China (32 EJ/yr) and OECD Europe (29 EJ/yr). Whereas OECD Asia Oceania, Latin America and the Middle East will have the lowest energy demand, of 9-11 $\mathrm{EJ} / \mathrm{yr}$.

High-efficiency pathways for urban buildings The energy efficiency pathways for buildings in ADV will reduce the electricity demand by $33 \%$ and fuel use by 46\%, compared with REF, in 2050. Compared with 2012, the global fuel use in this sector will decrease from $92 \mathrm{EJ} / \mathrm{yr}$ to $62 \mathrm{EJ} / \mathrm{yr}$, whereas electricity use will show a strong increase from $38 \mathrm{EJ} / \mathrm{yr}$ to $58 \mathrm{EJ} / \mathrm{yr}$. The final energy demand in the building sector per region will decrease in absolute terms. Although there will be substantial 
energy reductions in OECD regions, most developing countries will further increase their energy demands, especially for electricity. Table 6 shows the direct results for REF and ADV, whereas the estimated urban demands for buildings provided in Table 8 are calculated as described in section 2 . According to this analysis, and under the assumption that the urbanization rate will remain at the 2015 level until 2050, the annual energy demand for buildings in urban areas will increase by $27 \mathrm{EJ}$ under REF, from $57 \mathrm{EJ} / \mathrm{yr}$ to $84 \mathrm{EJ} / \mathrm{yr}$. However, ADV will lead to an overall reduction to $46 \mathrm{EJ} / \mathrm{yr}$ by 2050, $11 \mathrm{EJ} / \mathrm{yr}$ below the 2012 demand, although the population and GDP will continue to grow. Compared with REF, ADV will reduce the urban building demand by $38 \mathrm{EJ} / \mathrm{yr}$.

\begin{tabular}{|c|c|c|c|c|c|c|c|c|c|}
\hline \multicolumn{10}{|c|}{ Final energy use in “Other sectors" [EJ/yr] } \\
\hline \multirow[b]{2}{*}{ EJ per year } & \multicolumn{3}{|c|}{2012} & \multicolumn{3}{|c|}{2050 - REF } & \multicolumn{3}{|c|}{2050 - ADV } \\
\hline & $\begin{array}{l}\text { Total } \\
\text { final } \\
\text { energy }\end{array}$ & Fuels/heat & Electricity & $\begin{array}{l}\text { Total } \\
\text { final } \\
\text { energy }\end{array}$ & Fuels/heat & Electricity & $\begin{array}{l}\text { Total } \\
\text { final } \\
\text { energy }\end{array}$ & Fuels/heat & Electricity \\
\hline OECD North America & 24 & 12 & 12 & 33 & 17 & 16 & 16 & 8 & 8 \\
\hline OECD Asia Oceania & 8 & 4 & 4 & 9 & 5 & 4 & 5 & 3 & 2 \\
\hline OECD Europe & 21 & 14 & 7 & 29 & 20 & 9 & 15 & 10 & 5 \\
\hline $\begin{array}{l}\text { Eastern } \\
\text { Europe/Eurasia }\end{array}$ & 12 & 11 & 1 & 18 & 16 & 2 & 10 & 9 & 1 \\
\hline India & 10 & 9 & 1 & 17 & 15 & 2 & 13 & 12 & 1 \\
\hline China & 22 & 19 & 3 & 32 & 27 & 5 & 21 & 18 & 3 \\
\hline Other Asia & 10 & 8 & 1 & 18 & 16 & 3 & 12 & 10 & 2 \\
\hline Latin America & 5 & 4 & 2 & 11 & 8 & 3 & 6 & 4 & 2 \\
\hline Middle East & 5 & 3 & 2 & 11 & 7 & 4 & 6 & 4 & 2 \\
\hline Africa & 14 & 14 & 1 & 25 & 24 & 1 & 16 & 15 & 1 \\
\hline Global & 130 & 97 & 33 & 204 & 154 & 49 & 120 & 93 & 27 \\
\hline
\end{tabular}

Table 6: Final energy use in “Other sectors" under REF and ADV

\begin{tabular}{|c|c|c|c|c|c|}
\hline \multicolumn{2}{|c|}{$\begin{array}{l}\text { Comparison: Global final energy use for buildings } \\
\text { [EJ per year] } \\
\text { Scenario data: AR5 database (except ADV) }\end{array}$} & & 2050 & 2050 & 2050 \\
\hline Model & Scenario & & $\begin{array}{c}\text { Total final energy } \\
\text { buildings }\end{array}$ & $\begin{array}{l}\text { Buildings: } \\
\text { Fuels/heat }\end{array}$ & $\begin{array}{l}\text { Buildings: } \\
\text { Electricity }\end{array}$ \\
\hline Mesap/PlaNet & ADV & & 120 & 93 & 27 \\
\hline IMAGE 2.4 & AMPERE3-450 & Maximum & 166 & & \\
\hline IMAGE 2.4 & AMPERE2-450-LowEI-OPT & Average & 132 & & \\
\hline MESSAGE V4 & EMF27-450-EERE & Minimum & 89 & & \\
\hline IMAGE 2.4 & AMPERE3-450P-CE & Maximum & & & 164 \\
\hline MESSAGE V4 & AMPERE3-CF450 & Average & & & 151 \\
\hline MESSAGE V4 & AMPERE2-450-LowEI-HST & Minimum & & & 82 \\
\hline MESSAGE V4 & EMF27-550-NoCCS & Maximum & & 12.2 & \\
\hline IMAGE 2.4 & EMF27-FP-FullTech & Average & & 3.8 & \\
\hline MESSAGE V4 & EMF27-Base-LowEI & Minimum & & 0.2 & \\
\hline
\end{tabular}

Table 7: Comparison of global final energy use for buildings

ADV: Final energy use in residential, commercial, and services buildings; estimated demand for urban buildings [EJ/yr]

\begin{tabular}{|c|c|c|c|c|c|c|c|c|c|}
\hline \multirow[b]{2}{*}{ EJ per year } & \multicolumn{3}{|c|}{2012} & \multicolumn{3}{|c|}{2050 - REF } & \multicolumn{3}{|c|}{2050 - ADV } \\
\hline & Residential & $\begin{array}{l}\text { Commercial } \\
\text { \& services }\end{array}$ & $\begin{array}{c}\text { Estimated } \\
\text { urban } \\
\text { demand for } \\
\text { buildings }\end{array}$ & Residential & $\begin{array}{l}\text { Commercial } \\
\text { \& services }\end{array}$ & $\begin{array}{c}\text { Estimated } \\
\text { urban } \\
\text { demand for } \\
\text { buildings }\end{array}$ & Residential & $\begin{array}{l}\text { Commercial } \\
\text { \& services }\end{array}$ & $\begin{array}{c}\text { Estimated } \\
\text { urban } \\
\text { demand for } \\
\text { buildings }\end{array}$ \\
\hline $\begin{array}{l}\text { OECD North } \\
\text { America }\end{array}$ & 14 & 8 & \begin{tabular}{|l|}
18 \\
\end{tabular} & 19 & 11 & 25 & 9 & 6 & 12 \\
\hline $\begin{array}{l}\text { OECD Asia } \\
\text { Oceania }\end{array}$ & 3 & 4 & 4 & 4 & 4 & 5 & 2 & 2 & 3 \\
\hline OECD Europe & 14 & 5 & 14 & 19 & 7 & 20 & 10 & 4 & 10 \\
\hline $\begin{array}{l}\text { Eastern } \\
\text { Europe/Eurasia }\end{array}$ & 8 & 2 & 7 & 13 & 3 & 11 & 7 & 2 & 6 \\
\hline India & 8 & 1 & 2 & 14 & 1 & 3 & 11 & 1 & 2 \\
\hline China & 17 & 2 & 3 & 25 & 3 & 4 & 16 & 2 & 3 \\
\hline Other Asia & 8 & 1 & 2 & 16 & 1 & 3 & 10 & 1 & 2 \\
\hline Latin America & 4 & 0 & 2 & 8 & 1 & 4 & 4 & 0 & 2 \\
\hline Middle East & 4 & 1 & 1 & 8 & 1 & 3 & 5 & 1 & 2 \\
\hline Africa & 13 & 1 & 3 & 23 & 1 & 6 & 14 & 1 & 4 \\
\hline Global & $\begin{array}{r}94 \\
\end{array}$ & 23 & 57 & 149 & 34 & 84 & 90 & 18 & 46 \\
\hline \multicolumn{3}{|c|}{$\begin{array}{l}\text { Proportion of estimated urban building } \\
\text { demand in total demand: }\end{array}$} & $48 \%$ & & & $46 \%$ & & & $43 \%$ \\
\hline
\end{tabular}

Table 8: Final energy use in residential, commercial, and service buildings; estimated final energy demand for urban buildings 
Table 7 shows that the ADV projection for the final energy demand for buildings is just below the average for the selected 450 ppm scenarios. However, all other 450 ppm scenarios phase-out non-electrical heating supplies, whereas ADV uses substantial amounts of direct heating, mainly solar thermal collectors and district heating systems based on a mix of solar, geothermal, and bio energy. The IPCC AR5 scenario database does not provide further breakdown into energy demand projections for urban residential and commercial buildings, so no further comparison of the REF and ADV results given in Table 8 is possible.

\section{Energy demand pathways for the transport sector}

In 2014, the transport sector, including road, rail, aviation, and sea transport, required $27 \%$ of the global energy used [26], and $92.7 \%$ of the total transport energy demand was provided by oil products, with $2.5 \%$ from biofuels and only $1 \%$ from electricity [26]**. The breakdown of the final global energy demand under REF by transport mode shows that road transport (mainly passenger transport) will retain the largest share, with only a $3 \%$ reduction, from $71 \%$ to $68 \%$, in 2050 .

The overall energy demand in the transport sector was $90 \mathrm{EJ} / \mathrm{yr}$ in 2012 and will increase under REF to $150 \mathrm{EJ} / \mathrm{yr}$ in 2050. A drastic global reduction in the transport energy demand under $\mathrm{ADV}$, decreasing below the base year demand to $70 \mathrm{EJ} / \mathrm{yr}$, will be possible under the assumed combination of significant technical efforts-especially in terms of electrification —and a significant reduction in energy through modal shifts (see Table 9), a result of significant improvements in public transport, especially in urbanized areas.

\section{Deep mitigation pathway - changes required in the transport sector with a specific focus on urban areas}

The following measures are discussed as suitable to reduce the transport demand in urbanized areas:

- $\quad$ mixed-use developments that form mixedmodal urban hubs that are easily accessible destination points [27];

- $\quad$ improved spatial planning of urban areas and enhanced infrastructure for bicycles and pedestrians [28];

- a significant shift to electric vehicles supplied by renewable electricity such as light rails;

- a gradual reduction in the energy intensities of all modes with technological advances;

- a modal shift from individual cars to public transport systems;
Urban planning and urban transport policies play a key role in this concept, especially with regard to the modal shifts from road to all forms of public transport. Freight transport in urban areas involves small-to-medium-scale delivery vehicles, and their specific energy demand in MJ per tonnes kilometer is assumed to decrease significantly from around 5 $\mathrm{MJ} / \mathrm{t}-\mathrm{km}$ to $2.2 \mathrm{MJ} / \mathrm{t}-\mathrm{km}$ [44].

\section{Changes in transport modes}

Optimized public transport aims to reduce congestion and integration of walkways. [44] There are large differences in the specific energy consumption of transport modes: passenger transport by rail bound vehicles for example will consume $28 \%$ less energy than light-duty vehicles in 2050. The vehicle efficiency data that were used for REF and ADV are based on Oezdemir [44] and are presented in the appendix Table 19, Table 20, Table 20, Table 21 and Table 22.

Table 9 shows selected measures, reduction options, and indicators used to reduce the global transport demand in ADV. A normative estimate of the global transport demand in terms of all urban areas is not possible because the required data are unavailable.

\begin{tabular}{|c|c|c|}
\hline \multicolumn{3}{|c|}{$\begin{array}{l}\text { Transport Demand: } \\
\text { Selected measures, reduction options, indicators }\end{array}$} \\
\hline Measure & Reduction option & Indicator \\
\hline \multirow{2}{*}{$\begin{array}{l}\text { Reduction } \\
\text {.of transport } \\
\text { demand }\end{array}$} & $\begin{array}{l}\text { Reduction in volume of } \\
\text { passengers (compared with } \\
\text { REF) }\end{array}$ & $\begin{array}{l}\text { passenger- } \\
\mathrm{km} / \text { capita }\end{array}$ \\
\hline & $\begin{array}{l}\text { Reduction in the volume of } \\
\text { freight transport } \\
\text { (compared with REF) }\end{array}$ & $\begin{array}{l}\text { ton-km/unit of } \\
\text { GDP }\end{array}$ \\
\hline \multirow[t]{2}{*}{ Modal shift } & $\begin{array}{l}\text { Modal shift from trucks to } \\
\text { rail }\end{array}$ & MJ/ton-km \\
\hline & $\begin{array}{l}\text { Modal shift from cars to } \\
\text { public transport and from } \\
\text { aviation to rail }\end{array}$ & $\begin{array}{l}\text { MJ/passenger- } \\
\mathrm{km}\end{array}$ \\
\hline $\begin{array}{l}\text { Energy efficiency } \\
\text { improvements }\end{array}$ & $\begin{array}{l}\text { Shift to energy-efficient } \\
\text { passenger car drive trains } \\
\text { (battery electric vehicles, } \\
\text { hybrid and fuel cells, } \\
\text { hydrogen cars) and trucks } \\
\text { (hydrogen fuel cells, } \\
\text { electric batteries) }\end{array}$ & $\begin{array}{l}\text { MJ/passenger- } \\
\text { km, } \\
\text { MJ/ton-km }\end{array}$ \\
\hline
\end{tabular}

Table 9: Selection of measures and indicators used to reduce the global transport demand in ADV

Table 10 and Table 11 show the total transport volumes in billion ton per year and passenger kilometer per year for ADV compared with those in selected 450 ppm scenarios. The models use different values for the base year 2010; there are no data for 2012 and only limited data for 2015. To make these results comparable, we calculated the overall changes in percentages. 


\begin{tabular}{|l|c|c|c|c|c|c|}
\hline & \multicolumn{5}{|c|}{$\begin{array}{c}\text { Passenger transport } \\
\text { [billion passenger km per year] }\end{array}$} \\
\hline & $\mathbf{2 0 1 0}$ & $\mathbf{2 0 1 5}$ & \multicolumn{2}{|c|}{$\mathbf{2 0 5 0}$} & Max. & Change in \% \\
\hline & & & Min. & Average & & \\
\hline $\begin{array}{l}\text { IMACLIM V1.1/ } \\
\text { AMPERE2-450- } \\
\text { FullTech-LST }\end{array}$ & 33,880 & 35,780 & 29,540 & & & $87 \%$ \\
\hline $\begin{array}{l}\text { POLES EMF27 / } \\
\text { AMPERE2-450 (all) }\end{array}$ & 25,858 & not available & & 71,724 & & $277 \%$ \\
\hline $\begin{array}{l}\text { POLES EMF 27 / } \\
\text { EMF27-450-FullTech }\end{array}$ & 46,251 & not available & & & 138,801 & $300 \%$ \\
\hline \begin{tabular}{l} 
Mesap/PlaNet / ADV \\
\hline
\end{tabular} & 23,543 & 23,543 & & 63,546 & & $270 \%$ \\
\hline
\end{tabular}

Table 10: Passenger transport-annual kilometer projections in the transport sector in 2050 under various scenarios

\begin{tabular}{|l|c|c|c|c|c|c|}
\hline & \multicolumn{5}{|c|}{$\begin{array}{l}\text { Freight transport } \\
\text { [billion ton km per year] }\end{array}$} \\
\hline & $\mathbf{2 0 1 0}$ & $\mathbf{2 0 1 5}$ & \multicolumn{2}{|c|}{$\mathbf{2 0 5 0}$} & Max. & Change in \% \\
\hline Ecofys/TER2011 & 19,341 & not available & 46,524 & & & $241 \%$ \\
\hline $\begin{array}{l}\text { POLES } \\
\text { EMF27/AMPERE2- } \\
\text { 450-LimBio-LST }\end{array}$ & 46,268 & not available & & 122,065 & & $264 \%$ \\
\hline $\begin{array}{l}\text { POLES } \\
\text { AMPERE/AMPERE } \\
\text { 3-450 }\end{array}$ & 46,130 & not available & & & 145,596 & $316 \%$ \\
\hline \begin{tabular}{l} 
Mesap/PlaNet / ADV \\
\hline
\end{tabular} & 29,607 & 29,607 & & 61,782 & & \\
\hline
\end{tabular}

Table 11: Freight transport-annual ton kilometer projections in the transport sector in 2050 under various scenarios

\section{Decentralized and centralized generation systems in urbanized areas}

The installation of renewable energy systems within urbanized regions and their contribution to supply in those regions are still minor and the technical potential for renewable energy varies significantly under different geographic and meteorological conditions. Decentralized renewable energy systems will play a major role in the implementation of $\mathrm{ADV}$, tapping the technical and economical potential of a whole range of renewable energies. Solar photovoltaic generation and solar thermal systems for water and room heating can be installed on roofs and facades, and over rails, roads, and parking spaces, and devices can be floated on water reservoirs. An analysis of the city of Sydney, a 27 $\mathrm{km}^{2}$ area with a population density of 8,000 people per $\mathrm{km}^{2}$, found that "an area equal to $40 \%$ of the available roof surfaces could be used to accommodate PV, corresponding to $619 \mathrm{MW}_{\text {peak }}$ of potential PV capacity with an expected annual yield of $777 \mathrm{GWh}$. This equates to $22 \%$ of the $3,588 \mathrm{GWh}$ of load in the central-business district (CBD)". The resulting savings in potential $\mathrm{CO}_{2}$-equivalent emissions would be around 618 kt per year [29]. Another analysis of Apeldoorn, in the Netherlands, a city with a population of 157,700 people and a density of 464 persons per $\mathrm{km}^{2}$, concluded that the total estimated solar photovoltaic roof-top potential within the city limits could reach $319.9 \mathrm{MW}_{\text {peak, }}$ with the annual generation of 283.4 GWh/yr, enough to supply the entire city with electricity [30]. Cities located near the coast may benefit from offshore winds and also, in the future, from ocean energy technologies currently under development
[31]. The active involvement of civil society in planning resilient and sustainable cities will be crucial in increasing public acceptance and accelerating public participation. In 2000, Copenhagen was the first capital city to participate in a large offshore wind farm project only $2 \mathrm{~km}$ from the city coastline. The offshore wind farm "Middelgrunden" consists of a slightly curved line of 20 turbines, each with a generator size of $2 \mathrm{MW}$, and was built in a partnership between the municipality and local shareholders [32].

Furthermore, district heating schemes based on geothermal heating technologies to harvest geothermal energy within urban areas can be significant. Zhu et al. [33] concludes that within the city of Shanghai, the existing heat content in the urban aquifer is at least 22 times the annual heating demand of the city.

\section{Infrastructural changes in urban areas}

ADV will increase the average global share of variable renewables from $3 \%$ in the base year to $24 \%$ in 2030 and to over $50 \%$ after 2040 . In parallel, the electricity share of the transport sector will increase by a factor of 6 by 2025. The overall energy demand of the rail sector will increase by a factor 3 , and the electricity demand of road transport will increase from under $0.1 \%$ to $53 \%$ in 2050 .

These shares will vary significantly across regions. Regions with high and still increasing urbanization rates will have to substantially alter their infrastructures to implement the technologies presented in ADV. The effect of adding renewable power generation to a conventionally centralized 
power system will affect the way in which the system runs. The impact will depend on the share of renewable energy technology [34], [35]. A brief overview of the possible impacts of $100 \%$ renewable energy supply systems on urban infrastructures is presented in the next section.

\section{Efficient $100 \%$ renewable heating:}

infrastructural requirements for urban areas As outlined in ADV, a 100\% renewable heating system will involve increased amounts of electric heating systems, such as heat pumps, as well as solar collectors. With high population densities, residential roof space is limited. Therefore, the roof space of commercial buildings might be used for solar installations and the heat transported via district heating pipelines, while geothermal and bio energy heating technologies provide additional capacities. The existing infrastructure of the gas sector can potentially be converted to biogas and/or hydrogen systems. The impact on the urban infrastructure will be threefold:

1. Increased use of electric heating systems will increase the electrical load demand of buildings, which might require the enforcement of distribution grids [36].

2. Expansion and/or implementation of district heating and/or cooling pipelines to distribute renewable heat. Denmark is among the leading countries to expand its district heating network. In 2013, 63\% of the heating demand in private Danish houses was provided by district heating systems [37].

3. Conversion of existing gas pipelines to distribute hydrogen will depend on the actual pipeline material used, for example, polyethylene pipelines [38]. Individual technical analyses of the existing pipelines will be required to assess possible future costs.

Increased decentralized power generation: infrastructural requirements for urban areas A high density of distributed power generators, mainly composed of individual PV systems in a low-kilowatt capacity range, can exert a megawatt impact on single substations. This can result in a reverse load flow when generation exceeds demand within a cluster of the distribution grid. In that case, the surplus electricity must be exported to other regions of the grid. Substations will require specific upgrades to manage such reverse flows, which are further documented in Chojnowski et al. [39].

\section{Electric mobility: requirements for urban infrastructure}

- Modal shift: expansion of light rail systems will require the expansion of tracks and related infrastructure.

- Expansion of charging stations for individual electric vehicles in publicly accessible parking areas and privately owned charging stations will significantly change the distribution of load within existing distribution grids. Technical requirements will vary significantly, depending on local conditions [40].

The examples described above only outline a small fraction of the possible future requirements for urban planning. A comprehensive analysis is required, but is not within the scope of this paper.

\section{Estimated carbon emissions from urban buildings}

The regional energy-related carbon emissions from urban buildings were calculated based on the projected building energy demands shown in Table 6 and Table 8 and the emission intensities for the building sector under REF and ADV. While the overall annual emissions will increase from $1.6 \mathrm{Gt}$ $\mathrm{CO}_{2}$ to $1.9 \mathrm{Gt} \mathrm{CO}_{2}$ by 2050 under REF, a total phase-out of carbon emissions for this sector will be achieved on the ADV trajectory. The total cumulative emissions for urban buildings between 2012 and 2050 will be $69 \mathrm{Gt} \mathrm{CO}_{2}$ under REF and 33 $\mathrm{Gt} \mathrm{CO}_{2}$ under $\mathrm{ADV}$. The implementation of energy efficiency measures and 100\% renewable energy supplies under ADV will avoid the emission of 35 Gt $\mathrm{CO}_{2}$ between 2012 and 2050.

Table 12 provides an overview of the estimated $\mathrm{CO}_{2}$ emissions for buildings by region and under the two different trajectories. No comparison with AR5 450 ppm scenarios is possible because the database does not include specific $\mathrm{CO}_{2}$ emission data for buildings or any further breakdown for urban buildings. 


\begin{tabular}{|c|c|c|c|c|c|c|c|c|c|}
\hline \multicolumn{10}{|c|}{ Estimated $\mathrm{CO}_{2}$ emissions and reductions for urban buildings in million tons per year } \\
\hline $\begin{array}{l}\text { CO2 emissions } \\
\text { [Gt per year] }\end{array}$ & \multicolumn{3}{|c|}{2012} & \multicolumn{3}{|c|}{$\begin{array}{c}2030 \\
\text { Emission Reduction REF - ADV }\end{array}$} & \multicolumn{3}{|c|}{$\begin{array}{c}2050 \\
\text { Emission Reduction REF - ADV } \\
\text { (= REF emissions, ADV CO } \\
\text { emissions are phased-out) }\end{array}$} \\
\hline & Residential & $\begin{array}{l}\text { Commercial } \\
\text { \& services }\end{array}$ & $\begin{array}{l}\text { Total } \\
\text { urban } \\
\text { buildings }\end{array}$ & Residential & $\begin{array}{l}\text { Commercial } \\
\text { \& services }\end{array}$ & $\begin{array}{l}\text { Total } \\
\text { urban } \\
\text { buildings }\end{array}$ & Residential & $\begin{array}{l}\text { Commercial } \\
\text { \& services }\end{array}$ & $\begin{array}{l}\text { Total } \\
\text { urban } \\
\text { buildings }\end{array}$ \\
\hline $\begin{array}{l}\text { OECD North } \\
\text { America }\end{array}$ & 383 & 223 & 497 & 150 & 87 & 194 & 399 & 232 & 518 \\
\hline $\begin{array}{l}\text { OECD Asia } \\
\text { Oceania }\end{array}$ & 114 & 120 & 133 & 41 & 43 & 48 & 115 & 122 & 135 \\
\hline OECD Europe & 464 & 168 & 473 & 245 & 89 & 250 & 493 & 178 & 503 \\
\hline $\begin{array}{l}\text { Eastern } \\
\text { Europe/Eurasia }\end{array}$ & 226 & 58 & 201 & 144 & 37 & 129 & 331 & 85 & 295 \\
\hline India & 135 & 10 & 26 & 76 & 6 & 15 & 222 & 16 & 43 \\
\hline China & 425 & 52 & 76 & 302 & 37 & 54 & 560 & 68 & 101 \\
\hline Other Asia & 125 & 7 & 22 & 86 & 5 & 15 & 266 & 16 & 48 \\
\hline Latin America & 92 & 9 & 49 & 95 & 10 & 51 & 207 & 21 & 112 \\
\hline Middle East & 139 & 22 & 56 & 55 & 9 & 22 & 220 & 34 & 89 \\
\hline Africa & 116 & 4 & 30 & 87 & 3 & 22 & 346 & 13 & 88 \\
\hline $\begin{array}{l}\text { Total Urban } \\
\text { buildings }\end{array}$ & 2,218 & 673 & 1,565 & 1,282 & 325 & 801 & 3,158 & 786 & 1,931 \\
\hline
\end{tabular}

Table 12: Estimated energy-related $\mathrm{CO}_{2}$ emissions and reductions for urban buildings

\begin{tabular}{|c|c|c|c|}
\hline \multicolumn{4}{|c|}{ Estimated $\mathrm{CO}_{2}$ emissions and reductions for transport in million tons per year } \\
\hline $\begin{array}{l}\mathrm{CO}_{2} \text { emissions } \\
\text { [Gt per year] }\end{array}$ & 2015 & $\begin{array}{c}2030 \\
\text { Emission Reduction REF - ADV }\end{array}$ & $\begin{array}{c}2050 \\
\text { Emission Reduction REF }- \text { ADV } \\
\text { (= REF emissions, ADV CO } \text { ( }_{2} \text { emissions are } \\
\text { phased-out) }\end{array}$ \\
\hline $\begin{array}{l}\text { OECD North } \\
\text { America }\end{array}$ & 1,998 & 1,041 & 1,933 \\
\hline $\begin{array}{l}\text { OECD Asia } \\
\text { Oceania }\end{array}$ & 439 & 342 & 677 \\
\hline OECD Europe & 904 & 451 & 774 \\
\hline $\begin{array}{l}\text { Eastern } \\
\text { Europe/Eurasia }\end{array}$ & 304 & 130 & 430 \\
\hline India & 216 & 155 & 771 \\
\hline China & 698 & 404 & 1,011 \\
\hline Other Asia & 430 & 183 & 1,313 \\
\hline Latin America & 470 & 257 & 863 \\
\hline Middle East & 422 & 615 & 1,709 \\
\hline Africa & 285 & 173 & 314 \\
\hline $\begin{array}{l}\text { Total } \\
\text { Transports }\end{array}$ & 6,165 & 3,752 & 9,794 \\
\hline
\end{tabular}

Table 13: Estimated energy-related $\mathrm{CO}_{2}$ emissions for transport

\section{Discussion of key results and conclusions Scenario comparison}

The ADV scenario results in significantly lower energy demand projections compared to other mitigation pathways. This indicates that a decarbonized energy supply based on $100 \%$ renewable energy sources is expected to be even more dependent on ambitious efficiency targets and measures than scenarios with considerable shares of CCS and nuclear technologies. The electrification of heat supply and transportation is a core strategy for both targets achieving high efficiency in energy supply and enabling large-scale integration of renewable energies in all sectors. This has been addressed in most of the scenarios considered, however, with probably quite different pathways for alternative technology options. A detailed comparison of the mitigation pathways is not possible based on the IPCC database as it provides only aggregated scenario results for different sectors without breakdown of various technologies.

The ADV presented and compared with selected AR5 database 450 ppm scenarios has the following characteristics for 2050:

- Final energy demand is among the lowest of all the analyzed scenarios- $50 \%$ of those of the scenarios with the highest demand (MESSAGE V4, AMERE3-450).

- $\quad$ The projected electricity demand for 2050 under all the analyzed scenarios varies significantly, between 65,000 TWh/yr and $25,000 \mathrm{TWh} / \mathrm{yr}$. This is mainly attributable to the different electrification rates for transport and the heating sector. 
- $100 \%$ renewable energy scenarios, like ADV presented here, use high electrification rates for transport and the heating sector.

- $100 \%$ renewable energy scenarios tend to be dominated by solar PV systems and wind power generation.

\section{The urban perspective}

In 2015, urban regions housed around 54\% of the global population (Table 1) [41] and played a key role in the implementation of building standards. Although the high population densities and resulting land scarcity are challenging for the installation of renewable energy generators, they are advantageous for the implementation of efficient public and electric transport systems.

The projected energy demands for the building sector in 2050 in all the 450 ppm scenarios analyzed varied significantly less than those in the transport sector. Most will stabilize at the 2020 level, assuming that the increased demand of a growing population and efficiency measures correspond. However, the level of electrification in the heating sector varied significantly.

In the ADV scenario, the energy demand for urban buildings is reduced from $57 \mathrm{EJ} / \mathrm{yr}$ in the base year to $46 \mathrm{EJ} / \mathrm{yr}$ in 2050 . Thus, the energy demand in urban areas is expected to decrease by $20 \%$ below the 2012 demand, whereas the global population will continue to increase to 9.9 billion people, an increase of $40 \%$ relative to the base year. Renewable power and heating, predominantly solar and wind energy, and a wide range of energy-efficient technologies across all sectors, to reduce both demand and building materials, are expected to be key factors in achieving complete decarbonization. The total $\mathrm{CO}_{2}$ reduction potential for urban buildings is estimated to be around $35 \mathrm{Gt} \mathrm{CO}_{2}$. To reduce demand, key interventions for policy makers include energy efficiency standards for electrical appliances, transport technologies, and buildings. These efficiency standards should reflect the assumed energy intensities of low-carbon pathways.

ADV achieved a demand reduction for the transport sector, using modal shifts towards public transport, strict efficiency standards for vehicles and a shift towards electric mobility. To achieve a significant reduction in demand in the transport sector, the average energy intensity for cars should significantly decrease (as e.g. in ADV from $1.40 \mathrm{MJ}$ per passenger kilometer [MJ/p-km] to $0.26 \mathrm{MJ} / \mathrm{p}$ $\mathrm{km})$, which is only possible if fossil-fuel-based combustion engines are phased-out for new cars. In ADV, the annual passenger kilometers are expected to increase by $370 \%$ for rail bound systems, but by only 65\% for cars. Table 19 and Table 20 in the annex provide a detailed breakdown of the transport energy intensities per mode. No comparison with AR5 450 ppm scenarios is possible because the energy intensities for vehicles are not available.

Significant alteration of urban infrastructure in regard to public transport, electric mobility and accessibility for pedestrians and bicycle use are required in order to achieve both a significant modal shift and a significant share of "new" car technologies. The interconnection of urban infrastructures will require systems thinking and future planning to take new technology developments into account.

To achieve the energy related carbon emission targets of the Paris agreement the implementation of highly energy efficient buildings and transport systems in urbanized areas are mandatory and without alternative in all analyzed mitigation scenarios.

\section{Limitations}

To compare mitigation pathways, the AR5 database must be expanded, especially in terms of the energy intensities for specific technologies and detailed sectorial data. The latest actual statistical data for all parameters should be included. The quality of the data is a limiting factor in modeling specific sectorial energy pathways, such as those for urban environments. However, the level of detail in ADV, and also in the analyzed AR5 scenarios, is limited, especially with regard to urban transport. Furthermore, global energy assessments for freight transport, within and between world regions, are not part of the climate-mitigation scenarios and are therefore only qualitative. In addition, model assumptions influencing scenario results such as technology costs, utilization and efficiency are not contained in the database as well.

The feasibility of large proportions of variable renewable energy in power grids is currently under critical discussion in the scientific literature. A systems analysis that includes infrastructural requirements is necessary for future mitigation pathways to allow comprehensive cost-benefit analyses. ADV and all the scenarios of the AR5 database analyzed here only calculate energy balances for an entire year, and not on an hourly basis. 


\section{References}

[1] UNFCCC, “The Paris Agreement.” 2015.

[2] S. Teske, S. Sawyer, O. Schäfer, T. Pregger, S. Simon, T. Naegler, S. Schmid, E. D. Özdemir, J. Pagenkopf, F. Kleiner, J. Rutovitz, E. Dominish, J. Downes, T. Ackermann, T. Brown, Simon Boxer, R. Baitelo, and L. A. Rodrigues, "Energy [R]evolution - A sustainable world energy outlook," Greenpeace International, Global Wind Energy Council, SolarPowerEurope, Deutsches Zentrum für Luft- und Raumfahrt (DLR), 2015.

[3] S. Teske, T. Pregger, S. Simon, T. Naegler, W. Graus, and C. Lins, "Energy [R]evolution 2010 - a sustainable world energy outlook,” Energy Efficiency, vol. 4, no. 3, pp. 409-433, 2011.

[4] S. Teske, A. Zervos, C. Lins, M. Josche, W. Krewitt, T. Pregger, S. Simon, T. Naegler, S. Schmid, W. Graus, E. Bloomen, P. Baer, D. Ürge-Vorsatz, J. Rutovitz, and A. Atherton, "Energy [R] evolution - A sustainable world energy outlook,” Greenpeace International, European Renewable Energy Council (EREC), Deutsches Zentrum für Luft- und Raumfahrt (DLR), ecofys, 2010.

[5] O. Edenhofer, R. P. Madruga, Y. Sokona, K. Seyboth, P. Matschoss, S. Kadner, T. Zwickel, P. Eickemeier, G. Hansen, S. Schlömer, and C. von Stechow, Eds., Renewable Energy Sources and Climate Change Mitigation - Special Report of the Intergovernmental Panel on Climate Change. Cambridge University Press, 2012.

[6] C. Schlenzig, "Energy planning and environmental management with the information and decision support system MESAP,” International Journal of Global Energy Issues, vol. 12, no. 1-6, pp. 81-91, 1999.

[7] H. C. Gils and S. Simon, "Carbon neutral archipelago - 100\% renewable energy supply for the Canary Islands,” Applied Energy, vol. 188, pp. 342-355, 2017.

[8] W. Graus and K. Kermeli, “Energy Demand Projections for Energy [R]Evolution 2012,” Utrecht University, Netherlands, 2012.

[9] W. Graus, E. Blomen, and E. Worrell, "Global energy efficiency improvement in the long term: a demand- and supply-side perspective,” Energy Efficiency, vol. 4, no. 3, pp. 435-463, Aug. 2011.

[10] D. Thrän, T. Seidenberger, J. Zeddies, and R. Offermann, “Global biomass potentials — Resources, drivers and scenario results,” Energy for Sustainable Development, vol. 14, no. 3, pp. 200-205, 2010.

[11] REN21, “Renewables 2015 Global Status Report,” REN21 Secretariat (Renewable Energy Policy Network for the 21st Century), 2015.

[12] R. C. Pietzcker, D. Stetter, S. Manger, and G. Luderer, "Using the sun to decarbonize the power sector: The economic potential of photovoltaics and concentrating solar power," Applied Energy, vol. 135, no. 0, pp. 704-720, 2014.

[13] Y. Y. Deng, M. Haigh, W. Pouwels, L. Ramaekers, R. Brandsma, S. Schimschar, J. Grözinger, and D. de Jager, “Quantifying a realistic, worldwide wind and solar electricity supply,” Global Environmental Change, vol. 31, pp. 239-252, 2015.

[14] Solar Power Europe, “Global Market Outlook for Solar Power - 2015-2019,” Solar Power Europe, 2014.

[15] GWEC, “Global Wind Report - Annual Market Update 2014,” Global Wind Energy Council, 2014.

[16] WEC, "World Energy Resources - Charting the Upsurge in Hydropower development,” World Energy Council (WEC), 2015.

[17] GWEC, “Global Wind Report - Annual Market Update 2016,” Global Wind Energy Council, 2017.

[18] IRENA, “Renewable Energy Statistics 2017,” IRENA, 2017.

[19] Stephan Schmid and B. Frieske, “Technical-structural options in the transport sectors," German Aeorspace Center (DLR) - Institute for Vehicle Concepts, 2012.

[20] UNDESA, “World Population Prospects - The 2012 Revision,” United Nations Department for Economic and Social Affairs, 2013.

[21] IIASA, “IPCC AR5 Scenarios Database - RCP Database (VErsion 2.0),” International Institute für Applied Systems Analysis, 2014.

[22] B. P. Heard, B. W. Brook, T. M. L. Wigley, and C. J. A. Bradshaw, "Burden of proof: A comprehensive review of the feasibility of 100\% renewable-electricity systems,” Renewable and Sustainable Energy Reviews, vol. 76, pp. 1122-1133, 2017.

[23] M. Esteban and J. Portugal-Pereira, "Post-disaster resilience of a 100\% renewable energy system in Japan,” Energy, vol. 68, pp. 756-764, 2014.

[24] REN21, "Renewables 2017 Global Status Report,” REN21 Secretariat (Renewable Energy Policy Network for the 21st Century), 2017.

[25] T. W. Brown, T. Bischof-Niemz, K. Blok, C. Breyer, H. Lund, and B. V. Mathiesen, "Response to 'Burden of proof: A comprehensive review of the feasibility of $100 \%$ renewable-electricity systems," submitted to Elsevier, September 2017, 2017. 
[26] IEA, “Energy and Climate Change - World Energy Outlook Special Report,” International Energy Organization (IEA), 2015.

[27] D. Moser, “A new urban mobility concept,” Greenpeace \& Gehl Architects ApS, Copenhagen, 2015.

[28] Y. Ye, C. Wang, Y. Zhang, K. Wu, Q. Wu, and Y. Su, "Low-Carbon Transportation Oriented Urban Spatial Structure: Theory, Model and Case Study,” Sustainability, vol. 10, no. 1, 2017.

[29] Jessie Copper, Mike Roberts, and A. Bruce, "Spatial Analysis of Solar Potential in Sydney," Australian PV Institute (APV), University of New South Wales (UNSW), 2017.

[30] B. B. Kausika, O. Dolla, W. Folkerts, B. Siebenga, P. Hermans, and W. G. J. H. M. van Sark, "Bottomup analysis of the solar photovoltaic potential for a city in the Netherlands: A working model for calculating the potential using high resolution LiDAR data,” in Proceedings of the 2015 International Conference on Smart Cities and Green ICT Systems (SMARTGREENS), 2015.

[31] IEA, “Cities, towns and renewable energy - Yes in my front yard,” International Energy Agency (IEA), 2009.

[32] CEEO, “The Middelgrunden Offshore Wind Farm - A Popular Initiative,” Copenhagen Environment and Energy Office (CEEO), 2013.

[33] K. Zhu, P. Blum, G. Ferguson, K.-D. Balke, and P. Bayer, “The geothermal potential of urban heat islands,” Environmental Research Letters, vol. 5, no. 4, p. 044002, 2010.

[34] REN21, "Renewables Global Futures Report - Great Debates Towards 100\% Renwable Energy,” REN21 Secretariat (Renewable Energy Policy Network for the 21st Century), 2017.

[35] S. Teske, Tom Brown, Eckehard Tröster, Peter-Philipp Schierhorn, and T. Ackermann, “powE[R] 2030 A European grid for 3/4 renewable electricity by 2030,” Greenpeace, 2014.

[36] B. Morvaj, R. Evins, and J. Carmeliet, "Decarbonizing the electricity grid: The impact on urban energy systems, distribution grids and district heating potential,” Applied Energy, vol. 191, pp. 125-140, 2017.

[37] DEA, "District heating - danish experiences,” Danish Energy Agency (DEA), Danish Board of District Heating (DBDH), State of Green, 2015.

[38] P. E. Dodds and W. McDowall, “The future of the UK gas network,” Energy Policy, vol. 60, pp. 305316, 2013.

[39] Truman Chojnowski, David LaPlante, and J. Truong, "Reverse Power Mitigation System For Photovoltaic Energy Resources,” Worcester Polytechnic Institute (WPI), 2015.

[40] PlanGridEV, "Distribution grid planning and operational principles for EV mass roll-out while enabling DER integration,” 2016.

[41] World Bank, "Indicators - Agricultural \& Rural Development.” 2017.

[42] UNDESA, “World Urbanization Prospects - The 2014 Revision,” United Nations Department for Economic and Social Affairs, 2015.

[43] IEA, “World Energy Outlook 2014,” OECD Publishing, 2014.

[44] Enver Doruk Özdemir, Johannes Pagenkopf, Florian Kleiner, Ulrike Kugler, and S. Schmid, “Alternative Transport Technologies for Megacities,” German Aerospace Center (DLR) - Institute of Vehicle Concepts, 2015. 
Appendix

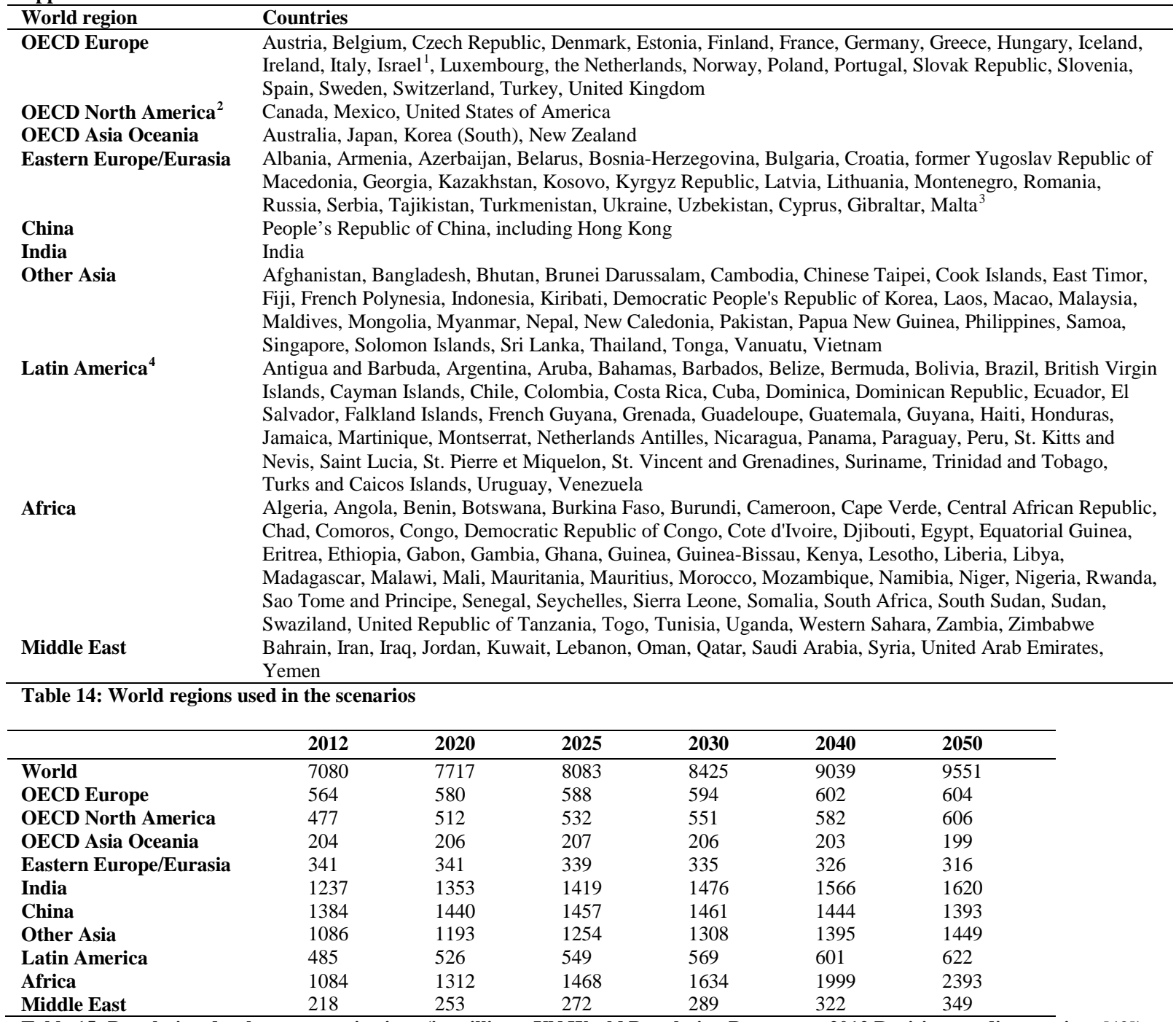

Table 15: Population development projections (in millions; UN World Population Prospects - 2012 Revision, medium variant [42])

\begin{tabular}{|l|l|l|l|l|}
\hline & $2012-2025$ & $2025-2040$ & $2040-2050$ & $2012-2050$ \\
\hline World & $3.4 \%$ & $3.4 \%$ & $2.2 \%$ & $3.1 \%$ \\
\hline OECD North America & $2.2 \%$ & $2.3 \%$ & $1.2 \%$ & $2.0 \%$ \\
\hline OECD Pacific & $1.8 \%$ & $1.5 \%$ & $0.5 \%$ & $1.3 \%$ \\
\hline OECD Europe & $1.9 \%$ & $1.6 \%$ & $1.0 \%$ & $1.5 \%$ \\
\hline Eastern Europe/Eurasia & $3.5 \%$ & $2.6 \%$ & $1.9 \%$ & $2.7 \%$ \\
\hline India & $6.6 \%$ & $5.5 \%$ & $3.1 \%$ & $5.2 \%$ \\
\hline China & $5.3 \%$ & $4.7 \%$ & $2.7 \%$ & $4.4 \%$ \\
\hline Other Asia & $4.5 \%$ & $4.5 \%$ & $3.0 \%$ & $4.0 \%$ \\
\hline Latin America & $3.5 \%$ & $3.0 \%$ & $2.2 \%$ & $2.9 \%$ \\
\hline Middle East & $3.9 \%$ & $3.4 \%$ & $3.2 \%$ & $3.5 \%$ \\
\hline Africa & $4.8 \%$ & $4.7 \%$ & $4.2 \%$ & $4.6 \%$ \\
\hline
\end{tabular}

Table 16: GDP development projections-average annual growth rates (2012-2040: IEA World Energy Outlook 2014 [43] and 2040-2050: DLR, own extrapolation)

\footnotetext{
${ }^{1}$ For statistical reasons, Israel is included in OECD Europe.

2 IEA WEO 2014 defines the region “OECD Americas” as USA, Canada, Mexico, and Chile, In contrast to the Energy [R]evolution Scenarios, which includes Chile with Latin America to maintain regional integrity.

${ }^{3}$ Cyprus, Gibraltar, and Malta are included in Eurasia for statistical reasons.

${ }^{4}$ Latin America includes Chile, in contrast to IEA WEO 2014.
} 


\begin{tabular}{|c|c|c|c|c|c|c|c|c|c|c|}
\hline & REF & ADV & REF & ADV & REF & ADV & REF & ADV & REF & ADV \\
\hline & \multicolumn{2}{|c|}{$\begin{array}{c}\text { Generation } \\
\text { [TWh/a] }\end{array}$} & \multicolumn{2}{|c|}{$\begin{array}{c}\text { Installed } \\
\text { capacity } \\
\text { [GW] }\end{array}$} & \multicolumn{2}{|c|}{$\begin{array}{c}\text { Annual Market } \\
\text { Volume } \\
\text { [GW/a] }\end{array}$} & \multicolumn{2}{|c|}{$\begin{array}{c}\text { Annual Growth Rate } \\
\text { based on Generation in } \\
\text { [TWh/a] }\end{array}$} & \multicolumn{2}{|c|}{$\begin{array}{c}\text { Electricity Share } \\
{[\% / a]}\end{array}$} \\
\hline 2030 & 30,639 & 29689 & 9,130 & 13146 & & & & & & \\
\hline 2050 & 42,622 & 40163 & 12,033 & 25835 & & & & & & \\
\hline PV 2030 & 630 & 5067 & 494 & 3725 & 16 & 288 & $5 \%$ & $19 \%$ & $13.7 \%$ & $17.1 \%$ \\
\hline PV 2050 & 1096 & 13613 & 803 & 9295 & 15 & 279 & $3 \%$ & $5 \%$ & $26.8 \%$ & $33.9 \%$ \\
\hline CSP2030 & 85 & 2552 & 26 & 635 & 1 & 59 & $11 \%$ & $39 \%$ & $5.7 \%$ & $8.6 \%$ \\
\hline CSP2050 & 303 & 14035 & 74 & 2555 & 2 & 96 & $7 \%$ & $9 \%$ & $22.0 \%$ & $34.9 \%$ \\
\hline \multicolumn{11}{|l|}{ Wind } \\
\hline on+offshore2030 & 1962 & 7737 & 807 & 3064 & 25 & 216 & $5 \%$ & $15 \%$ & $22.4 \%$ & $26.1 \%$ \\
\hline on+offshore 2050 & 3202 & 21673 & 1217 & 8040 & 21 & 249 & $3 \%$ & $6 \%$ & $40.4 \%$ & $54.0 \%$ \\
\hline \multicolumn{11}{|l|}{ Geothermal } \\
\hline \multicolumn{11}{|l|}{$\begin{array}{l}\text { for power } \\
\text { generation }\end{array}$} \\
\hline 2030 & 188 & 1149 & 28 & 171 & 1 & 14 & $6 \%$ & $21 \%$ & $3.3 \%$ & $3.9 \%$ \\
\hline 2050 & 425 & 4547 & 62 & 708 & 2 & 27 & $4 \%$ & $8 \%$ & $8.9 \%$ & $11.3 \%$ \\
\hline \multicolumn{11}{|l|}{ bioenergy } \\
\hline \multicolumn{11}{|l|}{$\begin{array}{l}\text { for power } \\
\text { generation }\end{array}$} \\
\hline 2030 & 1039 & 1993 & 199 & 405 & 5 & 21 & $4 \%$ & $8 \%$ & $6.8 \%$ & $6.7 \%$ \\
\hline 2050 & 1577 & 3193 & 293 & 742 & 5 & 17 & $2 \%$ & $3 \%$ & $8.2 \%$ & $7.9 \%$ \\
\hline \multicolumn{11}{|l|}{ ocean } \\
\hline 2030 & 10 & 363 & 4 & 131 & $\mathbf{0}$ & 12 & $15 \%$ & $31 \%$ & $0.9 \%$ & $1.2 \%$ \\
\hline 2050 & 76 & 2010 & 28 & 738 & 1 & 30 & $11 \%$ & $9 \%$ & $4.0 \%$ & $5.0 \%$ \\
\hline \multicolumn{11}{|l|}{ hydro } \\
\hline 2030 & 5207 & 4621 & 1544 & 1402 & 21 & 9 & $2 \%$ & $1 \%$ & $16.5 \%$ & $15.6 \%$ \\
\hline 2050 & 6431 & 4966 & 1878 & 1536 & 17 & 7 & $1 \%$ & $0 \%$ & $13.3 \%$ & $12.4 \%$ \\
\hline
\end{tabular}

Table 17: Renewable energy market developments under REF and ADV

\begin{tabular}{|l|c|c|}
\hline \multirow{2}{*}{ Region } & Relative substitution of air traffic with high-speed rail in 2050 under ADV \\
\cline { 2 - 3 } & \multicolumn{2}{|c|}{ Domestic } \\
\hline OECD Europe & $30 \%$ & $15 \%$ \\
\hline OECD North America & $20 \%$ & $10 \%$ \\
\hline OECD Asia Oceania & $20 \%$ & $10 \%$ \\
\hline Latin America & $30 \%$ & $10 \%$ \\
\hline Non-OECD Asia & $20 \%$ & $10 \%$ \\
\hline Eastern Europe/Eurasia & $10 \%$ & $10 \%$ \\
\hline China & $20 \%$ & $10 \%$ \\
\hline Middle East & $30 \%$ & $10 \%$ \\
\hline India & $20 \%$ & $10 \%$ \\
\hline Africa & $20 \%$ & $10 \%$ \\
\hline
\end{tabular}

Table 18 Relative substitution of air traffic with high-speed rail in 2050 under ADV

Energy Intensities and potential for passenger transport

\begin{tabular}{|l|l|l|l|}
\hline MJ/person km & $\mathbf{2 0 1 2}$ & $\mathbf{2 0 3 0}$ & $\mathbf{2 0 5 0}$ \\
\hline LDV & 1.5 & 0.7 & 0.3 \\
\hline $\begin{array}{l}\text { Passenger } \\
\text { Railway }\end{array}$ & 0.4 & 0.3 & 0.2 \\
\hline $\begin{array}{l}\text { Domestic } \\
\text { Aviation }\end{array}$ & 2.5 & 1.8 & 1.3 \\
\hline
\end{tabular}

Table 19: Energy Intensities and potential for passenger transport [27] 
Energy Intensities and potential for freight transport

\begin{tabular}{|l|l|l|l|}
\hline MJ/ton-km & $\mathbf{2 0 1 2}$ & $\mathbf{2 0 3 0}$ & $\mathbf{2 0 5 0}$ \\
\hline Railway & 0.12 & 0.14 & 0.09 \\
\hline Inland & & & \\
Navigation & 0.5 & 0.4 & 0.3 \\
\hline HDV & 1.6 & 1.3 & 0.8 \\
\hline MDV & 4.8 & 4.0 & 2.7 \\
\hline
\end{tabular}

Table 20 Vehicle technologies for city applications—-public transport; technical data for 2015-2020 [44]

Energy Intensities and potential for Light-Duty-Vehicles - REFERENCE

\begin{tabular}{|l|l|l|l|}
\hline MJ/person km & $\mathbf{2 0 1 2}$ & $\mathbf{2 0 3 0}$ & $\mathbf{2 0 5 0}$ \\
\hline OECD Europe & 1.4 & 1.0 & 0.9 \\
\hline OECD America & 2.4 & 1.6 & 1.0 \\
\hline OECD Asia Oceania & 1.3 & 0.9 & 0.6 \\
\hline Africa & 1.6 & 1.1 & 0.9 \\
\hline China & 1.4 & 0.9 & 0.6 \\
\hline India & 1.5 & 1.0 & 0.7 \\
\hline Latin America & 1.5 & 1.1 & 1.0 \\
\hline Other Developing Asia & 1.5 & 1.0 & 0.8 \\
\hline $\begin{array}{l}\text { Eastern } \\
\text { Europe/Transition }\end{array}$ & & & \\
Economies & 1.5 & 1.2 & 0.9 \\
\hline Middle East & 1.6 & 1.0 & 0.9 \\
\hline Weighted Average & $\mathbf{1 . 6}$ & $\mathbf{1 . 1}$ & $\mathbf{0 . 8}$ \\
\hline
\end{tabular}

Table 21: Energy Intensities and potential for passenger transport [44]

Energy Intensities and potential for Light-Duty-Vehicles - ADV

\begin{tabular}{|l|l|l|l|}
\hline MJ/person km & $\mathbf{2 0 1 2}$ & $\mathbf{2 0 3 0}$ & $\mathbf{2 0 5 0}$ \\
\hline OECD Europe & 1.4 & 0.6 & 0.2 \\
\hline OECD America & 2.4 & 0.9 & 0.2 \\
\hline OECD Asia Oceania & 1.3 & 0.6 & 0.3 \\
\hline Africa & 1.6 & 1.0 & 0.7 \\
\hline China & 1.3 & 0.6 & 0.2 \\
\hline India & 1.5 & 0.7 & 0.2 \\
\hline Latin America & 1.5 & 0.6 & 0.3 \\
\hline Other Developing Asia & 1.5 & 0.8 & 0.3 \\
\hline $\begin{array}{l}\text { Eastern } \\
\text { Europe/Transition }\end{array}$ & & & \\
Economies & 1.5 & 0.6 & 0.3 \\
\hline Middle East & 1.6 & 0.6 & 0.3 \\
\hline Weighted Average & $\mathbf{1 . 6}$ & $\mathbf{0 . 7}$ & $\mathbf{0 . 3}$ \\
\hline
\end{tabular}

Table 22: Energy Intensities and potential for passenger transport [44] 


\begin{tabular}{|c|c|c|c|}
\hline Final energy demand in $\mathrm{PJ} / \mathrm{yr}$ & REFERENCE: & & \\
\hline & 2012 & 2030 & 2050 \\
\hline Total (incl. non-energy use) & 360,650 & 485,226 & 587,701 \\
\hline Total energy use 1) & 326,859 & 441,590 & 538,502 \\
\hline Transport & 90,119 & 122,511 & 148,418 \\
\hline - Oil products & 82,794 & 109,825 & 128,112 \\
\hline - Natural gas & 3,765 & 5,427 & 9,020 \\
\hline - Biofuels & 2,486 & 5,352 & 7,982 \\
\hline - Synfuels & 0 & 0 & 0 \\
\hline - Electricity & 1,074 & 1,907 & 3,304 \\
\hline RES electricity & 225 & 480 & 865 \\
\hline - Hydrogen & 0 & 0 & 0 \\
\hline RES share Transport & $3 \%$ & $5 \%$ & $6 \%$ \\
\hline Industry & 106,313 & 151,290 & 186,496 \\
\hline - Electricity & 28,747 & 46,689 & 62,870 \\
\hline RES electricity & 6,034 & 11,746 & 16,449 \\
\hline - Public district heat & 5,446 & 6,473 & 6,446 \\
\hline RES district heat & 113 & 394 & 508 \\
\hline - Hard coal \& lignite & 25,402 & 34,396 & 36,033 \\
\hline - Oil products & 12,939 & 14,824 & 14,585 \\
\hline - Gas & 26,305 & 36,828 & 48,889 \\
\hline - Solar & 13 & 141 & 470 \\
\hline - Biomass & 7,441 & 11,909 & 17,158 \\
\hline - Geothermal & 20 & 29 & 45 \\
\hline - Hydrogen & 0 & 0 & 0 \\
\hline RES share Industry & $13 \%$ & $16 \%$ & $19 \%$ \\
\hline Other Sectors & 130,428 & 167,789 & 203,589 \\
\hline - Electricity & 38,088 & 61,705 & 87,266 \\
\hline RES electricity & 7,994 & 15,524 & 22,832 \\
\hline - Public district heat & 6,555 & 7,229 & 8,285 \\
\hline RES district heat & 136 & 440 & 654 \\
\hline - Hard coal \& lignite & 5,718 & 6,076 & 5,903 \\
\hline - Oil products & 17,894 & 18,940 & 19,849 \\
\hline - Gas & 24,960 & 34,091 & 43,036 \\
\hline - Solar & 790 & 1,964 & 3,359 \\
\hline - Biomass & 36,126 & 37,177 & 34,701 \\
\hline - Geothermal & 297 & 605 & 1,189 \\
\hline - Hydrogen & 0 & 0 & 0 \\
\hline RES share Other Sectors & $35 \%$ & $33 \%$ & $31 \%$ \\
\hline Total RES & 61,675 & 85,762 & 106,213 \\
\hline RES share & $19 \%$ & $19 \%$ & $20 \%$ \\
\hline
\end{tabular}

Table 23: Final energy demand 2012, 2030, 2050; REFERENCE case 


\begin{tabular}{|c|c|c|c|}
\hline Final energy demand in PJ/yr & ADV: & & \\
\hline & 2012 & 2030 & 2050 \\
\hline Total (incl. non-energy use) & 360,650 & 379,271 & 313,575 \\
\hline Total energy use 1) & 326,859 & 342,204 & 278,953 \\
\hline Transport & 90,119 & 85,457 & 56,534 \\
\hline - Oil products & 82,794 & 59,782 & 0 \\
\hline - Natural gas & 3,765 & 3,161 & 0 \\
\hline - Biofuels & 2,486 & 6,247 & 7,866 \\
\hline - Synfuels & 0 & 467 & 5,387 \\
\hline - Electricity & 1,074 & 12,027 & 29,242 \\
\hline RES electricity & 225 & 7,686 & 29,242 \\
\hline - Hydrogen & 0 & 3,773 & 14,039 \\
\hline RES share Transport & $3 \%$ & $19 \%$ & $100 \%$ \\
\hline Industry & 106,313 & 121,143 & 98,630 \\
\hline - Electricity & 28,747 & 43,008 & 52,409 \\
\hline RES electricity & 6,034 & 27,486 & 52,408 \\
\hline - Public district heat & 5,446 & 6,852 & 6,787 \\
\hline RES district heat & 113 & 2,925 & 6,787 \\
\hline - Hard coal \& lignite & 25,402 & 19,241 & 0 \\
\hline - Oil products & 12,939 & 5,425 & 0 \\
\hline - Gas & 26,305 & 27,636 & 0 \\
\hline - Solar & 13 & 4,440 & 11,791 \\
\hline - Biomass & 7,441 & 11,315 & 11,302 \\
\hline - Geothermal & 20 & 2,842 & 8,004 \\
\hline - Hydrogen & 0 & 382 & 8,338 \\
\hline RES share Industry & $13 \%$ & $41 \%$ & $100 \%$ \\
\hline Other Sectors & 130,428 & 135,605 & 123,788 \\
\hline - Electricity & 38,088 & 51,885 & 63,763 \\
\hline RES electricity & 7,994 & 33,158 & 63,762 \\
\hline - Public district heat & 6,555 & 9,188 & 11,919 \\
\hline RES district heat & 136 & 3,922 & 11,919 \\
\hline - Hard coal \& lignite & 5,718 & 1,437 & 0 \\
\hline - Oil products & 17,894 & 8,833 & 0 \\
\hline - Gas & 24,960 & 22,016 & 0 \\
\hline - Solar & 790 & 7,386 & 16,833 \\
\hline - Biomass & 36,126 & 31,508 & 19,322 \\
\hline - Geothermal & 297 & 3,019 & 9,606 \\
\hline - Hydrogen & 0 & 334 & 2,346 \\
\hline RES share Other Sectors & $35 \%$ & $58 \%$ & $100 \%$ \\
\hline Total RES & 61,675 & 145,102 & 278,949 \\
\hline RES share & $19 \%$ & $42 \%$ & $100 \%$ \\
\hline
\end{tabular}

Table 24: Final energy demand 2012, 2030, 2050; ADV case 